\title{
The Effectiveness of Monetary and Fiscal Policy in Serbia ${ }^{3}$
}

Article history

Received: 12 June 2013

Sent for revision: 21 June

Received in revised form: 02 July 2013

Accepted: 05 July 2013

Available online: 11 July 2013

\begin{abstract}
The effectiveness of fiscal and monetary policy has been the center of debate between Keynesians and the monetarists for a long time. However, the results of numerous empirical studies are inconclusive, suggesting that none of the policies can be thought of as superior to the other and their relative effectiveness in any economy depends on the prevailing economic and political conditions at any point in time. In order to determine the influence of fiscal and monetary policy on the economic activity in Serbia, we employed unit root and cointegration tests, as well as the regression analysis on the series of quarterly data for the period 2003-2012. The results obtained show that monetary policy is more effective in stimulating economic growth comparing to fiscal policy. Hence, the overall conclusion is that government should pay more attention to the fiscal policy to improve its efficiency in the future.
\end{abstract}

Key words: fiscal policy, monetary policy, economic growth, budget deficit, monetary aggregates

\footnotetext{
${ }^{1}$ University of Nis, School of Economics, biljana.rakic@eknfak.ni.ac.rs

2 University of Nis, School of Economics, tamara.radjenovic@eknfak.ni.ac.rs

${ }^{3}$ The paper is a result of research within the projects No. 179066 - "Improving the Competitiveness of the Public and Private Sector by Networking Competences in the Process of European Integration of Serbia" and III 42006 - "Research and Development of Energy Efficient and Environment Friendly Polygeneration Systems based on Renewable Energy Sources Utilization", funded by the Ministry of Education, Science and Technological Development of the Republic of Serbia
} 


\title{
Efikasnost monetarne i fiskalne politike u Srbiji
}

\begin{abstract}
Apstrakt: Efikasnost fiskalne i monetarne politike predstavlja centar debate između Kejnzijanaca i monetarista već duže vreme. Međutim, rezultati brojnih empirijskih istraživanja ne ukazuju na konkretan zaključak, već navode da nijedna od politika ne može biti posmatrana kao superiornija u odnosu na drugu i da njihova relativna efikasnost u bilo kojoj privredi zavisi od preovlađujućih ekonomskih i političkih uslova u određenom vremenskom trenutku. Da bismo utvrdili uticaj fiskalne i monetarne politike na privrednu aktivnost Srbije, primenili smo testove jediničnog korena i kointegracije, kao i regresionu analizu na seriju kvartalnih podataka za period 2003-2012. Dobijeni rezultati pokazuju da je monetarna politika u poređenju sa fiskalnom politikom efikasnija $u$ stimulisanju privrednog rasta. Iz tog razloga, krajnji zaključak je da vlada treba da posveti više pažnje fiskalnoj politici u cilju poboljšanja njene efikasnosti u budućnosti.
\end{abstract}

Ključne reči: fiskalna politika, monetarna politika, privredni rast, budžetski deficit, monetarni agregati

\section{Introduction}

The macroeconomic policy plays crucial role in providing sustainable and credible economic stability in a country, thus creating the environment for the fast economic growth. This task is primarily achieved through monetary and fiscal policies as its fundamental components. But, the necessary precondition for the successful functioning of an economy is the existence of coordinated activities of monetary and fiscal policies, since the absence of this coordination leads to a poor overall economic performance. Although these policies are conducted by two separate authorities, they are mutually dependent, and therefore, it is extremely important to accomplish a consistent and sustainable policy-mix framework, within which monetary and fiscal policies will be harmonized, to avoid possible inconsistencies (Kvrgić, Čolić, \& Vujović, 2011).

While fiscal policy is mainly concerned with the public expenditures and revenues, monetary policy deals with the discretionary control of money supply. Namely, through fiscal policy instruments and measures, modern governments participate in almost every part of social and economic life by influencing aggregate demand and supply, attempting to create the full employment conditions and moderate inflation, leading the policy of stable foreign trade balance and supporting steady economic development. Additionally, prudent and sustainable fiscal posture promotes "non-inflationary economic growth, low and stable levels of fiscal deficit and public debt, reduction of budget im- 
balances in situations of high fiscal deficit and public debt" (Chukuigwe \& Abili, 2008, p. 60).

On the other hand, monetary policy is mostly focused on accomplishing stability of prices thus avoiding high inflation rates, stable and stimulating exchange rate resulting in positive balance of payment and satisfactory level of employment. Besides, it influences the output level and economic growth rate and moderates excessive aggregate liquidity in the economy.

Indisputably, both monetary and fiscal policies have been proved to have inevitable roles in the macroeconomic stabilization, particularly within developing countries, but then again the Keynesians and the monetarists have had attentive debate over the usefulness of these policies. While the monetarists consider monetary policy to have greater influence on economic activity, the Keynesian believe that this is the case with fiscal policy. Generally, both the government spending increase or the expansionary monetary policy, resulting in the investment increase through reduced interest rates, contributes to an output increase (Rakic, Pesic, \& Radjenovic, 2012, p. 395). As a result, there are certain situations where monetary policy is effective and others in which fiscal policy performs better.

Notwithstanding the confirmed efficiency these policies have on economic activities in numerous economies, both policies have exerted insufficient or inadequate usage in Serbia. Therefore, the intention of this research is to test the comparative efficiency of monetary and fiscal policy in Serbia by employing the regression analysis. First, we will clarify the monetary and fiscal policy interactions and their influence on the economic growth, and then we will focus on the review of prior empirical studies. Special attention will be given to data used for empirical investigation. The remaining part of the paper is dedicated to the model specification, discussion of the obtained results and concluding remarks.

\section{Monetary and Fiscal Policy Interactions and Their Impact on Economic Growth}

Since the overall performance of macroeconomic policy depends on the mutual connections between the monetary and fiscal policy instruments, it is important to explore the different interaction channels between these policy instruments. When the influence of monetary policy on fiscal policy is in question, two direct transmission mechanisms can be identified - interest rates and inflation rates.

Firstly, interest rates have direct impact on fiscal positions by influencing servicing costs as well as sustainability of debt. According to Lane (2002, p. 5) 
"volatility in interest rates induces fluctuations in the level of the primary surplus required to stabilize the debt-output ratio". Namely, this effect is bigger when the debt level is higher.

Likewise, the level and volatility of inflation rates affects public finances. High inflation rates reduce the actual value of debt obligations unindexed in domestic-currency, thus leading to the increase in real tax burden and creating incentives to defer tax payments. Additionally, price inflation contributes to the public expenditures increase through salary increase for government employees. As a result, public finances become more unpredictable and fiscal planning extremely difficult.

Furthermore, monetary policy can have indirect effect on fiscal policy. When monetary strategy is directed toward smoothing the unnecessary output oscillations, then fiscal policy instruments are committed to accomplish social objectives and the efficiency at microeconomic level. But, when monetary policy is not committed to output stabilization, then primarily goal of fiscal authorities is pursuit of countercyclical stabilization policies.

Conversely, in recent years more consideration has been given to the possible influence of fiscal policy on the monetary policy. For example, expansionary fiscal policy may potentially jeopardize the stability of prices if it results in the economy overheating, thus demanding offsetting monetary intervention, the intensity of which will depend on the relative importance that price stability has over output stabilization for monetary authorities.

Additionally, monetary policy can be influenced by the level of public debt. Namely, an increase in government liabilities diminishes the level of savings and increases interest rates, resulting in the reduction of the potential output level, thus requiring a restrictive monetary policy. Other fiscal policy components that may well unfavorably impact the potential level of output and accordingly require a more restrictive monetary policy are: unproductive public projects, ineffective tax systems and too large transfer packages. Since the clear effect of such fiscal distortions on economic development is debatable, it is demanding for monetary authorities to determine the proper response.

Besides these indirect fiscal policy effects on the monetary policy, through the state of the real economy, price level dynamics may be directly affected by the public debt level. As Lane (2002, p. 7) explained "high nominal unindexed debt places pressure on the central bank to unleash a surprise inflation, in order to erode the real value of the debt". And above, empirical cross-country study conducted by Campillo \& Miron (1997) has proven that a strong correlation exists between high initial levels of public debt and average inflation rates.

Undoubtedly, monetary and fiscal policies are mutually interrelated in numerous ways, and this puts additional pressure on the monetary and fiscal author- 
ities to pool resources in order to accomplish efficient outcomes. But, the complexity of policy creation is even more difficult owing to the economic environment uncertainty as well as the nature of policy interactions.

As we mentioned earlier, the Keynesians-monetarists debate about the relative efficiency of monetary and fiscal policies in rising output, exists for years. Hence, it is significant to observe the cases in which fiscal policy performs better, and those in which only monetary policy works.

Those supporting Keynesian theory put attention on the liquidity trap, as the extreme special case in which fiscal policy works. When the economy finds itself in the liquidity trap situation, then any further money supply increase will not lead to the interest rate reduction, since interest rate has already reached its minimum level. If in such situation investments "are not big enough to provide expenditure equal to the full employment output, then monetary policy will fail to increase investments and restore full employment" (Rakic et al., 2012, p. 395). But, fiscal policy will increase the output through government expenditure augmentation, due to the fact that interest rates do not raise whatsoever and there is no crowding out of private investments to offset these effects.

The opposite situation, in which monetary policy works while fiscal policy does not, is based on the Quantity Theory of Money by which changes in stock of money (M) directly affect changes in national income value (PY) when the velocity of circulation is constant (V) (Ajisafe \& Folorunso, 2002, p. 29). Furthermore, if the price level $(P)$ is fixed, then $Y$ can change only if stock of money varies, meaning that change in government expenditure will have no effect on the real income, and thus fiscal policy is ineffective while monetary policy increases real output.

Given the above discussion, we will now focus on the previous empirical studies to explore which policy has demonstrated greater impact on the economic activity.

\section{Theoretical Background}

The impact of monetary and fiscal policies on economic growth has been one of the most debated and contested issues in economics. Despite the voluminous empirical literature investigating the relative effectiveness of fiscal and monetary policies and their influence on the economic growth in both developed and developing countries, the results are mixed.

Andersen and Jordan (1968) empirically investigated relations among measures of fiscal and monetary actions and total spending in United States, by employing regression analysis on quarterly data. GNP was used as the 
measure of economic activity, money stock and monetary base as measures of monetary actions, and high employment budget surplus, high employment expenditure and high employment receipt as measures of fiscal actions. These authors examined propositions by which the reaction of economic activity to fiscal actions compared to the monetary actions is greater (I), more predictable (II) and faster (III), and rejected them thus concluding that monetary actions should have greater confidence than fiscal actions.

These findings were also confirmed by Senbet (2011), who investigated the influence of monetary and fiscal policies on the U.S. real economic activity, using quarterly data between 1959:1 and 2010:2 by employing Granger causality tests and VAR models. The results he obtained from both models suggested that monetary policy affects the real output relatively better than fiscal policy.

Ajayi (1974) highlighted that in developing economies, such as Nigeria, the emphasis is constantly on fiscal policy. But the estimation results, obtained by employing ordinary least square (OLS) technique to the numerous variables of monetary and fiscal policies, revealed quite opposite situation where monetary influences are greater and more likely than fiscal ones. Therefore, he concluded that greater confidence should be placed on monetary actions.

These findings were confirmed by Ajisafe and Folorunso (2002) who examined series of annual data for the period 1970-1998 and discovered that monetary policy exerts greater impact on Nigerian economic activity comparing to fiscal policy.

The latest study by Okoro (2013) on the monetary policy influence on economic growth in Nigeria from 1970-2010, showed the existence of a long-run equilibrium relationship between instruments of monetary policy and economic growth. Namely, the results identified that negative correlations exist between GDP and interest and inflation rate, whereas money supply, exchange rate and credit to the economy were positively correlated with GDP.

Similar results were obtained by Elliot (1975), who studied the significance of changes in money supply compared to changes in government expenditure in order to explain variations in nominal GNP and reached the conclusion that nominal GNP is more sensitive to monetary movements than to government expenditure changes.

Furthermore, Batten and Hafer (1983) compared the relative monetary-fiscal impact for following countries - UK, US, Canada, Japan, France, Germany, during the late 1960s to the early 1980s, and their results were supportive toward greater monetary policy over fiscal policy influence across countries.

Also, Ali, Irum and Ali (2008) empirically investigated the comparative effect of both types of policies in case of four South Asian countries - Pakistan, India, 
Sri Lanka and Bangladesh for the period 1990-2007 and concluded that monetary policy is more powerful than fiscal policy in enhancing economic growth in case of South Asian economies.

These results were confirmed for Pakistan for the period 1981-2009 by Jawaid, Arif and Naeemullah (2010). Namely, they investigated the effectiveness of fiscal and monetary policy on economic growth in Pakistan using annual time series data. Although the co-integration results indicated that both policies have significant and positive effect on economic growth, the greater coefficient of monetary policy implied that monetary policy is more effective than fiscal policy in enhancing economic growth in Pakistan.

However, opposing results were obtained by Chowdhury (1986) in his research on the influence of monetary and fiscal actions on economic activity in Bangladesh. He made use of the OLS technique in his empirical investigation to test the impact of money supply, government expenditures and exports on the nominal income growth rate. The obtained results suggested greater impact on economic activity by fiscal actions compared to monetary actions, thus supporting the argument that impacts of fiscal policy on nominal income are more expectable than monetary impacts.

Similar results were obtained by Olaloye and Ikhide (1995) for Nigerian economy. Namely, they estimated monthly data for the period 1986-1991 and their findings revealed that fiscal policy is more influential on the economic activity than monetary policy, thus implying the relative effectiveness of fiscal policies in Nigeria at least in the period of depression.

Furthermore, Ogbole, Amadi and Essi (2011) studied the impact of fiscal policy on the economic growth in Nigeria during regulation (1970-1985) and deregulation (1986-2006) periods and concluded that the impact was marginally higher during deregulation, than in regulation period.

Research conducted by M'Amanja and Morrissey (2005) demonstrated that fiscal policy matters for economic growth in Kenya. Namely, productive consumption expenditure has a strong negative effect on growth, while government investment can enhance growth of real per capita income.

Besides, study by Enache (2009) discovered several measures of fiscal policy that contributed to the increase in the real GDP growth rate in Romania, i.e. "a reduction of distortionary public revenues compensated by a reduction of unproductive public expenditures, a reduction of budget deficit compensated by a reduction of the unproductive public expenditures, a reduction of the budget deficit compensated by a corresponding increase in the nondistortionary public revenues" (p. 511).

However, the empirical results from the research conducted by Waranya (2007) covering twelve developed and developing countries indicated that 
there is no definite consensus across these countries when the monetaryfiscal impact on economic activity is in question. Study tested quarterly data from the 1990s to 2004. According to the obtained results Waranya divided countries into three main categories, i.e. "monetary-policy-dominated, fiscalpolicy-dominated and monetary-fiscal-policies-mixed countries" (2007, p. 82), but even within third category, the impact of monetary and fiscal policies on the output level was not clearly distinguishable. Additionally, Waranya described four main implications between industrialized and developing countries (2007, pp. 82-83):

- $\quad$ while more opened developing countries exhibited relatively poor performance of public policy, the results for the industrialized countries were unclear, although in rather closed economies public policy had very limited power;

- $\quad$ while in developed countries, which adopted inflation-targeting, the monetary aggregates growth rate was no longer significant as monetary policy instrument, the situation was quite opposite with developing countries in which the framework was just adopted;

- $\quad$ in industrialized countries that had constant budged deficits and high levels of public debt, inflation rates were negatively influenced by the budget balance growth rate;

- government spending in developing countries had greater influence than in industrialized countries.

Finally, the dissimilarities in the results of the various researchers suggest that none of the policies can be thought of as superior to the other and their relative effectiveness in any economy depends on the prevailing economic and political conditions at any point in time.

From the above mentioned empirical studies, we can deduce that in order to determine the impact of monetary and fiscal policies on the economic activities, various techniques and variables are used. The variables used in these studies can be divided in several categories:

- monetary policy variables: interest rate, inflation rate, exchange rate, money supply, broad money;

- $\quad$ fiscal policy variables: public revenues, public expenditures, government investments, budget deficit, budget surplus;

- growth variables: logarithm of real GDP, GDP growth rate, nominal income, nominal income growth rate.

In this paper, by using some of above mentioned variables and methodologies, we will examine the relative influence of monetary and fiscal policies on the economic activity in Serbia and thus attempt to fill the existing gap in the literature. 


\section{Fiscal and Monetary Policy in Serbia}

For better understanding of fiscal and monetary implications on the economic growth, it is necessary to closely look at fiscal and monetary policies and their objectives in Serbia. Namely, Serbia is a transition country and as many other former socialist countries of the Central and Eastern Europe (CEE), its public sector roles had to be redefined in order to reach the market economy.

However, the transition process was not easy because it was followed by the reduction of real GDP, employment and living conditions of citizens, resulting in drastic decline in public revenues, while public expenditures were not declining at the same trend. Consequently, the process of fiscal adjustment was complicated and long-lasting, especially in the first years of transition. Comparing to other CEE countries, the transition and fiscal adjustment process in Serbia started ten years later with a very bad initial economic and social position. During 1990s public expenditures were very high (due to the country recovery from the NATO bombing, high subsidies to the economy and large public administration) while on the other hand public revenues were lower than in other CEE countries (due to declining economic activity and foreign trade, tax evasion etc.).

From 2000 onwards the fiscal policy has been relatively loose and both public revenues and expenditures have significantly increased, but public investments have still been on the low level of 2.3\% GDP (Šestović, 2008). Due to the successfully conducted tax reform and better control of public revenues collection, their participation in GDP has increased, but Serbia still reported budget deficits. During 2004-2005 fiscal adjustments on the expenditure side resulted in budget surplus. Namely, owing to high inflows from privatization, which enabled expenditures increase without new public debt, fiscal policy turned to more expansive path in the next period.

Despite expansive fiscal policy, the tendency of public debt reduction was continued and in 2008 it reached the level below 30\% of GDP (Ministry of Finance, 2012). But, economic crisis severely hit the Serbian economy in 2009. Negative consequences for public finance were extensive and by the end of 2011 public debt exceeded the limit of $45 \%$. In crisis conditions fiscal policy had hard task to moderate the negative consequences of crisis, without jeopardizing public finance sustainability in medium and long term. By employing discretionary measures, fiscal policy played important role in stabilizing economy in 2009 when budget deficit increased to $4.5 \%$ of GDP. But, the short term budget deficit increase is a reasonable measure, due to the significant economic contraction and external adjustment.

In the next mid-term period, the main challenge for the fiscal policy will be a credible strategy for strengthening public finance and sustainable level of 
deficit and debt trends. This is supported by defined fiscal rules by which (Government of the Republic of Serbia, 2010, p. 30):

- annual target fiscal deficit in mid-term should be 1\% GDP;

- general government debt, excluding restitution-related obligations, should not exceed $45 \%$ GDP.

In addition to fiscal policy measures for overcoming crisis conditions, numerous monetary policy measures were adopted, such as: favorable loans for liquidity and investments, consumer loans for citizens, residential loans and reduction of the required reserves. In Serbia monetary policy is mostly used for coping with inflation.

Namely, inflation rate had been increasing during 1997 to 2001 and reached the level of as much as $95.01 \%$. In 2002 it declined to $19.49 \%$, and in the following year to $9.88 \%$. But, in the two following years inflation rate increased and reached the level of $16.12 \%$ in 2005 . Then, it declined to $6.39 \%$ in 2007 , while in 2008 reached the level of $12.41 \%$. In order to limit further increase in the inflation rate, Government and National bank of Serbia signed the Agreement on Inflation Targeting whereby they changed the monetary policy regime to inflation targeting from 1 January 2009. As a result, the inflation rate declined in the following period and in 2010 reached the level of $6.14 \%$. Unfortunately, inflation rate started to increase again and in 2012 reached the level of $12.2 \%$ (Fig. 1).

Consequently, the primary objective of monetary policy is to reach the inflation target in the medium term, thus contributing to the financial system stability and sustainable economic growth. Monetary policy objective for 2013 is expressed numerically as the annual percentage change in the consumer price index and is set at $4.0 \% \pm 1.5$ percentage points, which is above the quantitative definition of price stability and the inflation targets of advanced economies $(2.0 \%$ or $2.5 \%)$ (National Bank of Serbia, 2012). The inflation target is based on the assessment that the process of structural reforms and price liberalization, i.e. nominal, real and structural convergence towards the European Union, will not be completed until 2014. 
Figure 1 - Inflation in Serbia from 1997 to 2012

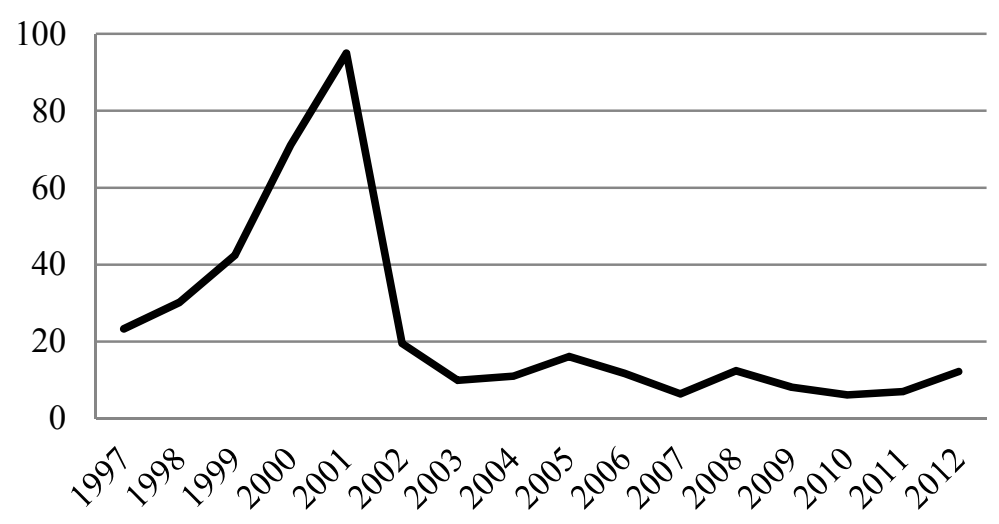

Source: National Bank of Serbia, Statistical Office of the RS

Having discussed the main implications and objectives of fiscal and monetary policy in Serbia, we will proceed with the empirical analysis of their relative effectiveness on the economic activity.

\section{Data and Methodology}

For measuring the monetary policy impact on the economic growth, the narrow money and the broad money are used, while for measuring the influence of the fiscal policy, the government revenues, government expenditures and government budget deficit are employed. Our a-priory expectations are that GDP is positively related to both monetary and fiscal policy variables. The empirical results in this study have been attained by using STATA $8.0 \mathrm{com}-$ puter package for econometric data analysis and estimation.

Data observed in the study are acquired from the official websites of the National Bank of Serbia and the Statistical Office of the Republic of Serbia. Estimated database contains quarterly data starting from the first quarter of 2003 to the fourth quarter of 2012.

In the analyzed period, government revenues oscillated between $17.38 \%$ (the lowest value in the first quarter of 2003) and $31.05 \%$ (the highest level in the first quarter of 2007). From 2003 to 2007 government revenues were on the increase, but starting from 2008 they had a declining trend, except in 2010 when they showed slight recovery. Over the entire period their average participation rate in GDP was $24.31 \%$. 
However, the situation with government expenditures was quite different. They oscillated between $21.48 \%$ (the lowest value in the first quarter of 2003) and $30.39 \%$ (the highest level in the fourth quarter of 2010). In the first three years of the analyzed period, government expenditures exhibited declining trend, but afterwards they started increasing and reached the level of $29.06 \%$ of GDP in 2012.

As regards budget deficit, it started to decline from 2003 to 2004 , in the following years budget surplus was reported, but then again starting from 2008 and the beginning of the global economic crisis, budget deficit was steadily increasing and reached the average level of $5.76 \%$ of GDP in 2012 .

On the other hand, the narrow money as \% of GDP was rising year after year and reached $38.08 \%$ in 2007 . In the following years, declining periods dominated until 2012 when slight recovery was reported. When broad money is in question the increasing trend was recorded from 2003 (38.30\%) till 2009 $(60.03 \%)$ indicating that investors were more likely to invest their funds through financial intermediaries than capital market. The main reason for this is certainly the increase in interest rates that reached $5.81 \%$ in 2009 , which represents the augmentation of $85.86 \%$ comparing to 2008 .

GDP was mostly increasing during the analyzed period. Namely, it reached the level of RSD 1461 billion in 2003 and RSD 1854 in 2012. But, it should be mentioned that in 2009 GDP declined comparing to 2008 from RSD 1907 billion to RSD 1840 billion, as a consequence of the negative impact of the global economic crisis. Negative GDP growth rates were reported in $2009-$ $3.5 \%$ and in $2012-1.9 \%$.

The evaluation of monetary and fiscal policy effects on economic growth in Serbia starts with the following hypotheses:

$H_{01}$ : The monetary policy variables do not have a significant effect on the economic growth, thus, $H_{01}: \beta_{i}=0$

$H_{A 1}$ : The monetary policy variables have a significant effect on the economic growth, thus, $H_{A 1}: \beta_{i} \neq 0$

and

$H_{02}$ : The fiscal policy variables do not have a significant effect on the economic growth, thus, $H_{02}: \beta_{k}=0$

$H_{A 2}$ : The fiscal policy variables have a significant effect on the economic growth, thus, $H_{A 2}: \beta_{k} \neq 0$ 
where:

$\beta_{i}$ - the coefficients of monetary policy variables

$\beta_{k}-$ the coefficients of fiscal policy variables

$H_{0}$ - null hypothesis

$H_{A}$ - alternative hypothesis.

In order to analyze the influence of the above mentioned variables, we will use the methodology of multiple regression analysis and the OLS econometric method. Functional form, on which our econometric model is based, can be presented as follows:

$$
Y=F\left(x_{1}, x_{2}, x_{3}, \ldots, x_{n}\right)
$$

Where, $Y$ represent economic growth, i.e. GDP or dependent variable, $x_{1}$ to $x_{n}$ are independent variables i.e. monetary and fiscal variables, while $F$ stands for function. The OLS linear regression equation based on the above function can be written as follows:

$$
Y=\alpha+\beta_{1} x_{1}+\beta_{2} x_{2}+\ldots+\beta_{n} x_{n}+\varepsilon
$$

In this paper several regression equations will be estimated:

$$
\begin{aligned}
& \ln G D P=\alpha+\beta \ln M 1+\varepsilon \\
& \ln G D P=\alpha+\beta \ln M 2+\varepsilon \\
& \ln G D P=\alpha+\beta \ln B D+\varepsilon \\
& \ln G D P=\alpha+\beta \ln E+\varepsilon \\
& \ln G D P=\alpha+\beta_{1} \ln R+\beta_{2} \ln B D+\varepsilon \\
& \ln G D P=\alpha+\beta_{1} \ln M 1+\beta_{2} \ln B D+\varepsilon \\
& \ln G D P=\alpha+\beta_{1} \ln M 2+\beta_{2} \ln B D+\varepsilon
\end{aligned}
$$

where:

GDP - Gross Domestic Product (in constant prices where 2005 is reference year)

$$
\begin{aligned}
& \text { M1 - narrow money } \\
& \text { M2 - broad money } \\
& \text { BD - budget deficit }
\end{aligned}
$$


Rakić B. et al.: The Effectiveness of Monetary and Fiscal Policy in Serbia

$\mathrm{R}$ - government revenues

$\mathrm{E}$ - government expenditures

In - logarithm value of variable

$\alpha$ - regression constant

$\beta_{1}, \beta_{2}$ - regression coefficients

$\varepsilon$ - error term

But, before we proceed with evaluation of the above regression models, we will first start with unit root tests used for testing stationarity in the time series data and the cointegration used for testing the long-run relationship between the independent and dependent variables. The results of stationarity analysis by using Dickey-Fuller (DF) and Augmented Dickey-Fuller (ADF) tests are presented in Table 1.

Table 1 - Unit root tests for variables

\begin{tabular}{|c||c||c||c||}
\hline Variable & DF & ADF & Order of integration \\
\hline LGDP & -5.581 & -5.121 & $\mathrm{I}(0)$ \\
\hline LM1 & -2.109 & -1.895 & $\mathrm{I}(1)$ \\
\hline LM2 & -1.222 & -1.269 & $\mathrm{I}(1)$ \\
\hline LR & -5.357 & -2.754 & $\mathrm{I}(1)$ \\
\hline LE & -7.005 & -3.552 & $\mathrm{I}(0)$ \\
\hline LBD & -5.053 & -1.248 & $\mathrm{I}(1)$ \\
\hline$\Delta \mathrm{LM} 1$ & -7.260 & -4.965 & $\mathrm{I}(1)$ \\
\hline$\Delta \mathrm{LM} 2$ & -6.107 & -5.162 & $\mathrm{I}(1)$ \\
\hline$\Delta \mathrm{LR}$ & -9.957 & -6.702 & $\mathrm{I}(1)$ \\
\hline$\Delta \mathrm{LBD}$ & -15.612 & -4.954 & $\mathrm{I}(1)$ \\
\hline Note: $L=$ natural logarithm, $\Delta=$ first difference operator \\
\hline
\end{tabular}

Source: Authors' calculations

The ADF is based on the following regression equation with constant and trend (Gujarati, 2003):

$$
\Delta Y_{t}=\beta_{1}+\beta_{2} T+\delta Y_{t-1}+\alpha_{i} \sum_{i=1}^{k} \Delta Y_{t-1}+\varepsilon_{t}
$$

The null hypothesis is that $\delta=0$, indicating that the series is nonstationary; whereas the alternative hypothesis is that $\delta<0$. This test follows a tau statistic $(\tau)$. If the computed absolute value of $\tau$ statistic exceeds the critical value than null hypothesis should be rejected, the series is stationary or integrated of order zero $-\mathrm{I}(0)$. However, if there is a unit root, and by differencing the series once it becomes stationary, then it is integrated of order one $-\mathrm{I}(1)$. 
Using DF test, all variables except for narrow money and broad money are considered stationary at their levels since each computed absolute value of $\tau$ statistic exceeds the $1 \%$ critical value. Again, using ADF test, the null hypothesis of non-stationarity is rejected for GDP at $1 \%$ critical value and for government expenditures at $5 \%$ critical value. Additional tests are conducted to determine whether first differencing contributes to the stationarity of variables and this is also reported in Table 1 . The reported findings confirm that after differencing once all variables become stationary.

In order to test whether variables are cointegrated the Engle-Granger (EG) method will be applied on the residuals from the long run equilibrium (Brooks, 2002). The null hypothesis implies the non-stationarity of the residuals, i.e. having unit roots, while the alternative hypothesis suggests that there are no unit roots in the residuals. This test consists of two phases - firstly, the long run equation is estimated and secondly, DF and ADF tests are applied on the residuals from the equation estimated in the first phase.

Table 2 - Cointegration tests for variables

\begin{tabular}{|c|c|c|c|c|c|}
\hline Variable & constant & $\beta_{i}$ & $\beta_{k}$ & DF & ADF \\
\hline $\begin{array}{l}\text { LGDP on LM1 } \\
\& \text { LBD }\end{array}$ & $\begin{array}{c}10.23537 \\
{[0.000]}\end{array}$ & $\begin{array}{c}0.2263343 \\
{[0.000]}\end{array}$ & $\begin{array}{c}0.0010501 \\
{[0.945]}\end{array}$ & $-5.554^{*}$ & $-6.681^{*}$ \\
\hline $\begin{array}{l}\text { LGDP on LM2 } \\
\text { \& LBD }\end{array}$ & $\begin{array}{l}10.84213 \\
{[0.000]}\end{array}$ & $\begin{array}{c}0.1686781 \\
{[0.000]}\end{array}$ & $\begin{array}{c}0.0032213 \\
{[0.841]}\end{array}$ & $-5.362^{\star}$ & $-6.630^{*}$ \\
\hline LGDP on LM1 & $\begin{array}{c}10.48605 \\
{[0.000]}\end{array}$ & $\begin{array}{c}0.2075247 \\
{[0.000]}\end{array}$ & & $-6.585^{*}$ & $-8.720^{*}$ \\
\hline LGDP on LM2 & $\begin{array}{c}11.07026 \\
{[0.000]}\end{array}$ & $\begin{array}{c}0.1540966 \\
{[0.000]}\end{array}$ & & $-6.573^{*}$ & $-8.373^{*}$ \\
\hline LGDP on LBD & $\begin{array}{c}12.44663 \\
{[0.000]}\end{array}$ & & $\begin{array}{c}0.0563584 \\
{[0.003]}\end{array}$ & $-4.085^{\star \star}$ & $-3.408^{* * *}$ \\
\hline LGDP on LR & $\begin{array}{c}9.949809 \\
{[0.000]}\end{array}$ & & $\begin{array}{c}0.25797 \\
{[0.000]}\end{array}$ & $-6.683^{*}$ & $-7.789^{*}$ \\
\hline LGDP on LE & $\begin{array}{c}10.39194 \\
{[0.000]}\end{array}$ & & $\begin{array}{c}0.2189997 \\
{[0.000]}\end{array}$ & $-5.298^{*}$ & $-5.654^{*}$ \\
\hline
\end{tabular}

Source: Authors' calculations

The results of cointegration tests are reported in Table 2. Based on the obtained results we can conclude that all variables are cointegrated meaning that a long-term relationship exists among them. Once we proved the existence of the relationship between monetary and fiscal policy variables and GDP, we will now estimate the above presented regression models.

\section{Discussion of Regression Analysis Results}


Regression analysis results of the estimated regression models are presented in Table 3. First model (R1) estimates the impact of narrow money on the economic growth. The basic assumption of the model is a positive value of the regression coefficient - $\beta$. Based on the values in Table 3 , we can see that the basic assumption is satisfied, i.e. the value of regression coefficient shows a positive correlation - if we increase narrow money by $1 \%$, GDP will increase by $0.21 \%$. This model suggests positive correlation between monetary policy and economic growth, since $52.38 \%$ change in the economic growth is explained by this model.

Table 3 - Regression analysis results

\begin{tabular}{|c|c|c|c|c|c|c|c|}
\hline \multirow{2}{*}{$\begin{array}{c}\text { Independent } \\
\text { variable }\end{array}$} & \multicolumn{7}{|c|}{ Regression model } \\
\hline & R1 & R2 & R3 & R4 & R5 & R6 & R7 \\
\hline constant & $\begin{array}{c}10.48605 \\
(6.28) \\
{[0.000]}\end{array}$ & $\begin{array}{c}11.07026 \\
(32.82) \\
{[0.000]}\end{array}$ & $\begin{array}{c}12.44663 \\
(73.37) \\
{[0.000]}\end{array}$ & $\begin{array}{c}10.39194 \\
(32.17) \\
{[0.000]}\end{array}$ & $\begin{array}{c}9.906087 \\
(32.14) \\
{[0.000]}\end{array}$ & $\begin{array}{c}10.23537 \\
(19.86) \\
{[0.000]}\end{array}$ & $\begin{array}{c}10.84213 \\
(25.18) \\
{[0.000]}\end{array}$ \\
\hline In M1 & $\begin{array}{c}0.2075247 \\
(26.07) \\
{[0.000]}\end{array}$ & & & & & $\begin{array}{c}0.2263343 \\
(4.59) \\
{[0.000]}\end{array}$ & \\
\hline In M2 & & $\begin{array}{c}0.1540966 \\
(5.76) \\
{[0.000]}\end{array}$ & & & & & \begin{tabular}{|c|}
0.1686781 \\
$(4.10)$ \\
{$[0.000]$}
\end{tabular} \\
\hline In BD & & & \begin{tabular}{|c|}
0.0563584 \\
$(3.20)$ \\
{$[0.003]$}
\end{tabular} & & $\begin{array}{c}0.0004781 \\
(0.04) \\
{[0.967]}\end{array}$ & $\begin{array}{c}0.0010501 \\
(0.07) \\
{[0.945]}\end{array}$ & $\begin{array}{c}0.0032213 \\
(0.20) \\
{[0.841]}\end{array}$ \\
\hline $\ln R$ & & & & & $\begin{array}{c}0.2606185 \\
(8.62) \\
{[0.000]}\end{array}$ & & \\
\hline $\ln \mathrm{E}$ & & & & $\begin{array}{c}0.2189997 \\
(8.06) \\
{[0.000]}\end{array}$ & & & \\
\hline $\mathrm{R}^{2}$ & 0.5374 & 0.4942 & 0.2614 & 0.6307 & 0.7979 & 0.6278 & 0.5896 \\
\hline$\overline{R^{2}}$ & 0.5238 & 0.4793 & 0.2360 & 0.6209 & 0.7834 & 0.5968 & 0.5554 \\
\hline F-statistics & $\begin{array}{c}39.50 \\
{[0.0000]}\end{array}$ & $\begin{array}{c}33.22 \\
{[0.0000]}\end{array}$ & $\begin{array}{c}10.26 \\
{[0.0033]}\end{array}$ & $\begin{array}{c}64.89 \\
{[0.0000]}\end{array}$ & $\begin{array}{c}55.27 \\
{[0.0000]}\end{array}$ & $\begin{array}{c}20.24 \\
{[0.0000]}\end{array}$ & $\begin{array}{c}17.24 \\
{[0.0000]}\end{array}$ \\
\hline Note: $t$ values & $\sin (), p$ va & ues in [] & & & & & \\
\hline
\end{tabular}

Source: Authors' calculations

Second model (R2) evaluates the impact of broad money on the economic growth. The basic assumption of the model is positive value of the regression coefficient - $\beta$. The coefficient of broad money shows positive correlation with economic growth and is statistically significant meaning that if the broad money increases by $1 \%$, GDP will increase by $0.15 \%$. Variable in this model explain $47.93 \%$ changes in the economic growth. 
Third model (R3) analyses the influence of budget deficit on the economic growth. Regression coefficient is statistically significant and shows strong positive correlation. If budget deficit increases by $1 \%$, GDP will increase by $0.06 \%$. This variable explains only $23.60 \%$ changes in the economic growthFourth model (R4) analyzes the impact of government expenditures on the GDP. This variable is statistically significant and also has a positive correlation with GDP. If government expenditures increase by $1 \%$, GDP will increase by $0.22 \%$. This model explains $62.09 \%$ changes in GDP.

Apart from previous models that analyze the impact of single variables on the economic growth, fifth model (R5) evaluates the joint impact of fiscal policy variables on the economic growth - budget deficit and government revenues. Parameters of the estimated regression model show that budget deficit is statistically insignificant for the economic growth, while government revenues are statistically significant. Both regression coefficients exhibit positive correlation, i.e. their increase lead to increase of GDP. If the government revenues increase by $1 \%$, GDP will increase by $0.26 \%$. Variables in this model explain $78.34 \%$ changes in the economic growth.

Finally, models (R6) and (R7) evaluate the joint impact of monetary and fiscal policy variables on the economic growth. All regression coefficients exhibit positive correlation with GDP, but fiscal policy variable is statistically insignificant, while both monetary policy variables are statistically significant. These models explain $59.68 \%$ and $55.54 \%$ changes in the economic growth, respectively.

\section{Conclusion}

In this paper, the comparative analysis of the fiscal and monetary policy influences on the economic activity in Serbia is presented. The results of the unit root and cointegration tests indicate long-term relationship between monetary and fiscal policy variables and GDP. The regression models show that the monetary policy variables positively influence economic growth. Thereby, narrow money plays crucial role considering its stimulating influence on the economic growth.

Regarding fiscal policy variables, the results are mixed. Namely, both budget deficit and government expenditures exhibit strong positive correlation with GDP, but when government revenues are included in the model the budget deficit coefficient becomes statistically insignificant, thus its potential to increase economic growth is not exploited. Similar results were obtained in the models that combine the monetary and fiscal policy variables. While monetary policy variables have strong positive correlation with GDP, the fiscal policy variables have no power in enhancing economic growth. 
Obtained results certainly imply that monetary policy is relatively effective in stimulating Serbian economy compared to fiscal policy. Such results may partially be explained by the unsatisfactory level of coordination between monetary and fiscal policies in previous period. During the forthcoming period, monetary and fiscal policymakers will be faced with several challenges, especially concerning the achievement of the macroeconomic stability and economic growth through low inflationary environment, sustainable balance of payment and fiscal position. Thus, special attention in the next period should be given to the fiscal policy in order to enhance its efficiency.

\section{References}

Ajayi, S.I. (1974). An Econometric Case Study of the Relative Importance of Monetary and Fiscal Policy in Nigeria. The Bangladesh Economic Review, 2(2), 559-576. Retrieved from http://www.jstor.org/stable/40795755.

Ajisafe, R.A., \& Folorunso, B.A. (2002). The Relative Effectiveness of Fiscal and Monetary Policy in Macroeconomic Management in Nigeria. The African Economic and Business Review, 3(1), 23-40. Retrieved from www.theaebr.com/v3n1Ajisafe.pdf

Ali, S., Irum, S., \& Ali, A. (2008). Whether Fiscal Stance or Monetary Policy is Effective for Economic Growth in Case of South Asian Countries. The Pakistan Development Review, 47(4), 791-799. Retrieved from www.pide.org.pk/pdf/PDR/2008/Volume4/791-799.pdf

Andersen,L.C. and Jordan, J.L. (1968). Monetary and Fiscal Actions: A Test of TheirRelative Importance in Economic Stabilization. Federal Reserve Bank of St. Louis Review, Nov, 11-24. Retrieved from http://research.stlouisfed.org/publications/review/68/11/Monetary Nov1968.pdf

Batten, D.S., \& Hafer, R.W. (1983). The Relative Impact of Monetary and Fiscal Actions on Economic Activity: A Cross-Country Comparison. Federal Reserve Bank of St Louis Review, 65(1), 5-12. Retrieved from http://research.stlouisfed.org/publications/review/83/01/Relative Jan1983.pdf

Brooks, C. (2002). Introductory Econometrics for Finance. Cambridge: Cambridge University Press.

Campillo, M., \& Miron, J. (1997). Why Does Inflation Differ Across Countries. In C.D. Romer \& D. Romer (Eds.), Reducing Inflation: Motivation and Strategy. (pp. 335362). Chicago: The University of Chicago Press.

Chowdhury, A.R. (1986). Monetary and Fiscal Impacts on Economic Activities in Bangladesh: A Note. The Bangladesh Development Studies, 14(2), 101-106. Retrieved from http://www.jstor.org/stable/40795239.

Chukuigwe, E.C., \& Abili, I.D. (2008). An Econometric Analysis of the Impact of Monetary and Fiscal Policies on Non-Oil Exports in Nigeria: 1974-2003. African Economic and Business Review, 6(2), 59-73. Retrieved from www.theaebr.com/Vol6No2Fall2008Chukuigwe.pdf.

Elliot, J.W. (1975). The Influence of Monetary and Fiscal Actions on Total Spending: The St. Louis Total Spending Equation Revisited. Journal of Money Credit and Banking, 7(2), 181-192. Retrieved from http://www.jstor.org/stable/1991348. 
Enache, C. (2009). Fiscal Policy and Economic Growth in Romania. Annales Universitatis Apulensis Series Oeconomica, 11(1), 502-512. Retrieved from http://oeconomica.uab.ro/upload/lucrari/1120091/50.pdf

Revised Memorandum on Budget and Economic and Fiscal Policy for 2011 with Forecasts for 2012 and 2013. Belgrade: Government of the Republic of Serbia.

Gujarati, D.N. (2003). Basic econometrics. Boston: McGraw-Hill.

Jawaid, S.T., Arif, I., \& Naeemullah, S.M. (2010). Comparative Analysis of Monetary and Fiscal Policy: A Case Study of Pakistan. NICE Research Journal, 3, 58-67.

Kvrgić, G., Čolić, Z., \& Vujović, T. (2011). Značaj koordinacije mera monetarne i fiskalne politike. Bankarstvo, 40(3-4), 32-61.

Lane, R.P. (2002). Monetary - Fiscal Interactions in an Uncertain World: Lessons for European Policymakers. Institute for International Integration Studies. Trinity College Dublin and CEPR. Retrieved from. Retrieved from http://www.tcd.ie/Economics/TEP/2002 papers/TEPNo13PL22.pdf.

M'amanja, D., \& Morrissey, O. (2005). Fiscal Policy and Economic Growth in Kenya. Centre for Research in Economic Development and International Trade. University of Nottingham. Research Pape. Retrieved from http://www.nottingham.ac.uk/credit/documents/papers/05-06.pdf

-Ministry of Finance. (2012). Bulletin Public Finance January 2012. Belgrade: Ministry of Finance.

National Bank of Serbia. Retrieved from www.nbs.rs

-National Bank of Serbia. (2012). Monetary Policy Programme of the National Bank of Serbia in 2013. RS Official Gazette,

Ogbole, O.F., Amadi, S.N., \& Essi, I.D. (2011). Fiscal Policy: Its Impact on Economic Growth in Nigeria 1970 to 2006. Journal of Economics and International Finance, $\quad 3(6), \quad 407-417 . \quad$ Retrieved from http://www.academicjournals.org/jeif/pdf/pdf\%202011/June/Ogbole $\% 20 \% 20$ et $\%$ 20al.pdf.

Okoro, A.S. (2013). Impact of Monetary Policy on Nigerian Economic Growth. Prime Journal of Social Science, 2(2), 195-199. Retrieved from http://www.primejournal.org/PJSS/pdf/2013/feb/Okoro.pdf

Olaloye, A.O., \& Ikhide, S.I. (1995). Economic Sustainability and the Role of Fiscal and Monetary Policies in a Depressed Economy: The Case Study of Nigeria. Sustainable Development, 3, 89-100.

Rakic, B., Pesic, M., \& Radjenovic, T. (2012). The Effects of Fiscal Policy in the Contemporary Economic Crisis Conditions. FACTA UNIVERSITATIS Series: Economics and Organization, 9(4), 393-405. Retrieved from http://facta.junis.ni.ac.rs/eao/eao201204/eao201204-01.pdf

Senbet, D. (2011). The Relative Impact of Fiscal versus Monetary Actions on Output: A Vector Autoregressive (VAR) Approach. Business and Economic Journal, 25, 1-11. Retrieved from http://astonjournals.com/manuscripts/Vol2011/BEJ25 Vol2011.pdf.

Statistical Office of the Republic of Serbia. Retrieved from www.stat.gov.rs

Šestović, L. (2008). Fiskalna politika u Srbiji u prvim godinama tranzicije i predstojeći izazovi. In Tekuća privredna kretanja, ekonomska politika i strukturne promene u Srbiji 2007/2008. (pp. 91-109). Retrieved from http://bs.scribd.com/doc/28314753/Fiskalna-Politika-u-Srbiji.

Waranya, A. (2007). International Differences in the Relative Monetary-Fiscal Influence on Economic Stabilization. Journal of International Economic Studies, 21, 69-84. 
Rakić B. et al.: The Effectiveness of Monetary and Fiscal Policy in Serbia

Retrieved

from

http://repo.lib.hosei.ac.jp/bitstream/10114/226/1/21atchariyachanvanich.pdf. 